\title{
Bioturbation as a potential mechanism influencing spatial heterogeneity of North Carolina seagrass beds
}

\author{
Edward C. Townsend, Mark S. Fonseca* \\ National Oceanic and Atmospheric Administration, National Marine Fisheries Service, Southeast Fisheries Science Center, \\ Beaufort Laboratory, Beaufort, North Carolina 28516-9722, USA
}

\begin{abstract}
The frequency and duration of bioturbation pits and their potential role in altering or maintaining the spatial heterogeneity of seagrass beds were evaluated within beds dominated by a mix of Zostera marina and Halodule wrightii near Beaufort, North Carolina, USA. Our evaluations were performed systematically over large (1/4 ha) sites in order to make generalizations as to the effect of bioturbation at the scale at which seagrass landscape patterns are discerned. Eighteen $50 \times 50 \mathrm{~m}$ sites, representing a wide range of seagrass bottom cover, were surveyed seasonally for 2 yr at $1 \mathrm{~m}$ resolution to describe the spatial heterogeneity of scagrass cover on the sites. We measured a number of environmental factors, including exposure to waves, tidal current speed, percent seagrass cover, sediment. organic content and silt-clay content, seagrass shoot density, above- and belowground seagrass biomass, and numbers of bioturbation pits in the bottom. Seagrass bed cover ranged from 13 to $100 \%$ of the site, with 0 to $1.3 \%$ of the seafloor within the site showing discernable bioturbation pits. Three sites were selected for detailed study where we marked both existing bioturbation pits and new ones as they formed over time. Pits were measured every 1 to $3 \mathrm{~d}$ for width, length and depth until the pit was obscured; pit duration averaged $\sim 5 \mathrm{~d}$ with an observed maximum of $31 \mathrm{~d}$. We found a bimodal frequency distribution of pits, with small pits $\left(0.05\right.$ to $\left.0.4 \mathrm{~m}^{2}\right)$ occurring more frequently than large pits $\left(>0.4 \mathrm{~m}^{2}\right)$, although the fewer large pits could account for over a third of bed margin disruption on a site. Even with a small amount of the open sand areas showing disturbance at any one time $(\leq 1.3 \%)$, based on the rate of new pit formation, the return interval for disturbance of a given square meter of unvegetated bottom among seagrass patches was $\sim 1.2$ yг. Pits often occurred withın $1 \mathrm{~m}$ of seagrass bed margins and were of sufficient depth to fully disturb the seagrass rhizosphere. Because of the frequency of pit formation, their depth and proximuty to patch edges, it appears that bioturbation may play an important role in the maintenance of seagrass landscape pattern in the Beaufort area through disruption of the bed margins and, potentially, seedling recruitment.
\end{abstract}

KEY WORDS: Seagrass - Landscape pattern Bioturbation Disturbance

\section{INTRODUCTION}

Patchiness or spatial heterogeneity of seagrass beds arising from disturbance (sensu White \& Pickett 1985; 'environmental fluctuations and destructive events') has often been attributed to physical factors such as wave action (Taylor \& Lewis 1970, den Hartog 1971, Patriquin 1975) and tidal currents (O'Gower \&

\footnotetext{
- Addressee for correspondence

E-mail:mark.fonseca@noaa.gov.us
}

Wacasey 1967, Scoffin 1970, Taylor \& Lewis 1970, Fonseca et al. 1983). Seagrass beds are also frequently disturbed as the result of anthropogenic impacts (e.g. light reduction, dredging, motor boat impacts) as well as biogenic reworking (bioturbation) of the sediment.

Soft-bottom marine environments in general have been shown to be strongly affected by bioturbation as well. The effects of this bioturbation on community and trophic structure have been well documented in seagrass beds from a variety of geographic locations (see review by Short \& Wyllie-Echeverria 1996). The fauna 
performing this sediment reworking includes hemichordates and rays (Grant 1983), holothuroideans (Rhoads \& Young 1971), polychaetes (Eckman et al. 1981, Philippart 1994), and other infaunal burrowers. Other studies have focused on the effects of biogenic reworking by fishes on meiofauna and have demonstrated high levels of bottom disturbance, with each square meter of bottom being disturbed within 70 to 120 d (Billheimer \& Coull 1988, Thrush et al. 1991). Similarly, studies that have focused on the seagrassbioturbation interaction have described a variety of bioturbators. Ogden et al. (1973) documented the effect of the echinoid Diadema antillarum on the formation of grazing halos in seagrass beds adjacent to West Indian patch reefs. Similarly, Camp et al. (1973) and Valentine \& Heck (1991) demonstrated the potentially strong role of Lytechinus variegatus in producing unvegetated areas in seagrass beds in the northern Gulf of Mexico. Orth. (1975) documented the destruction of large areas of eelgrass Zostera marina in the Chesapeake Bay to the feeding activity of the cownose ray Rhinoptera honasus. Suchanek (1983) and Harrison (1987) demonstrated the negative impacts of the burrowing shrimp Callianassa spp. on the seagrasses Thalassia testudinum and Zostera spp., respectively. More recently, Philippart (1994) demonstrated that sediment reworking by lugworms (Arenicola spp.) presented sufficient disturbance to inhibit the expansion of Zostera noltii bed margins.

Valentine et al. (1994), however, found that even large animals such as rays were apparently unable to create unvegetated patches within existing Thalassia testudinum beds in the northern Gulf of Mexico, and that only very large rays were capable of producing pits at the bed-sand margin that resulted in damage to these seagrasses' rhizomes. They also found that sandollars Mellita quinquiesperforata did not disturb these edges whereas stonecrab Menippe spp. burrows were disruptive. They point out that the deep rhizome layer and comparatively larger rhizome diameter of $T$ testudinum (as compared to $Z$. marina or Halodule wrightii as found in the Beaufort area) may insulate these plants from ray and sandollar disturbance.

One possible result of these varied sources of bioturbation is the development (or at least maintenance) of a fragmented pattern of plant coverage for some seagrass species, as suggested by Camp et al. (1973). With the exception of the photographic documentation by Orth (1975), few experiments have been conducted at landscape scales (i.e. the horizontal extent over which bed pattern is shown to be scale independent; for the Beaufort area, this is greater than $\sim 10 \mathrm{~m}$ horizontal distance, Fonseca 1996). Rather, experiments of biological disturbance in seagrass beds have been conducted over somewhat smaller areas (e.g. $-4.8 \mathrm{~m}$ horizontal extent; Valentine et al. 1994) requiring extrapolation to larger scales. One possible reason that bioturbation has not been systematically evaluated over larger areas in seagrass is that large-scale patterns of fragmented seagrass coverage have historically been associated with disturbance in the form of waves and tidal currents (Patriquin 1975, Fonseca et al. 1983, Kirkman \& Kuo 1990) and anthropogenic impacts (Sargent et al. 1995).

In an attempt to bridge the gap between smaller scale experiments and landscape-scale responses, our objectives in this study were to: (1) determine the temporal and spatial distribution of bioturbation in a range of seagrass habitats (dominated by a mix of Zostera marina and Halodule wrightii) with varying spatial heterogeneity, while (2) measuring the size and persistence of the bioturbation effects (which were evidenced by the formation of excavation pits). From these assessments we compared the kind and intensity of disturbance with levels found in other studies and considered the potential of this disturbance to affect the growth of seagrass bed margins and thus influence seagrass landscape pattern.

\section{MATERIALS AND METHODS}

Field surveys of bioturbation intensity. As part of an ongoing study of seagrass landscapes and their relation to physical disturbance across a gradient of hydrodynamic regimes (Bell et al. 1994, Murphey \& Fonseca 1995, Fonseca \& Bell 1998), we conducted summer and fall (May-June and October-November 1991 and 1992) surveys of seagrass bed coverage at the $1 \mathrm{~m}$ scale over 18 haphazardly located $50 \times 50 \mathrm{~m}$ sections of seagrass beds near Beaufort, North Carolina, USA $\left(34^{\circ} 41^{\prime} \mathrm{N}, 76^{\circ} 37^{\prime} \mathrm{W}\right.$ ) (Fig 1). These sections of mixed Zostera marina and Halodule wrightii beds (with occasional Ruppia maritima) were chosen to represent a locally observed gradient in seagrass coverage that graded from discrete, -1 to $2 \mathrm{~m}$ diameter patches separated by several meters of unvegetated sand, to continuous cover (see Fig. 2).

During 2 yr of seasonal (May-June/NovemberDecember) surveys of these 18 sites, we observed and recorded the location of what appeared to be bioturbation pits (see Fig. 2). Each site was composed of a permanently marked, $50 \times 50 \mathrm{~m}$ grid which was systematically surveyed for seagrass cover or bioturbation pits with $1 \mathrm{~m}$ resolution (Murphey \& Fonseca 1995, Fonseca \& Bell 1998). If a pit occurred in a given $1 \mathrm{~m}$ grid cell, that cell was recorded as a bioturbation pit. The size of the pits and the presence of numerous rays in the area (Rhinoptera spp., Dasyatis spp.) led us to suspect rays in particular as being the primary agent of 


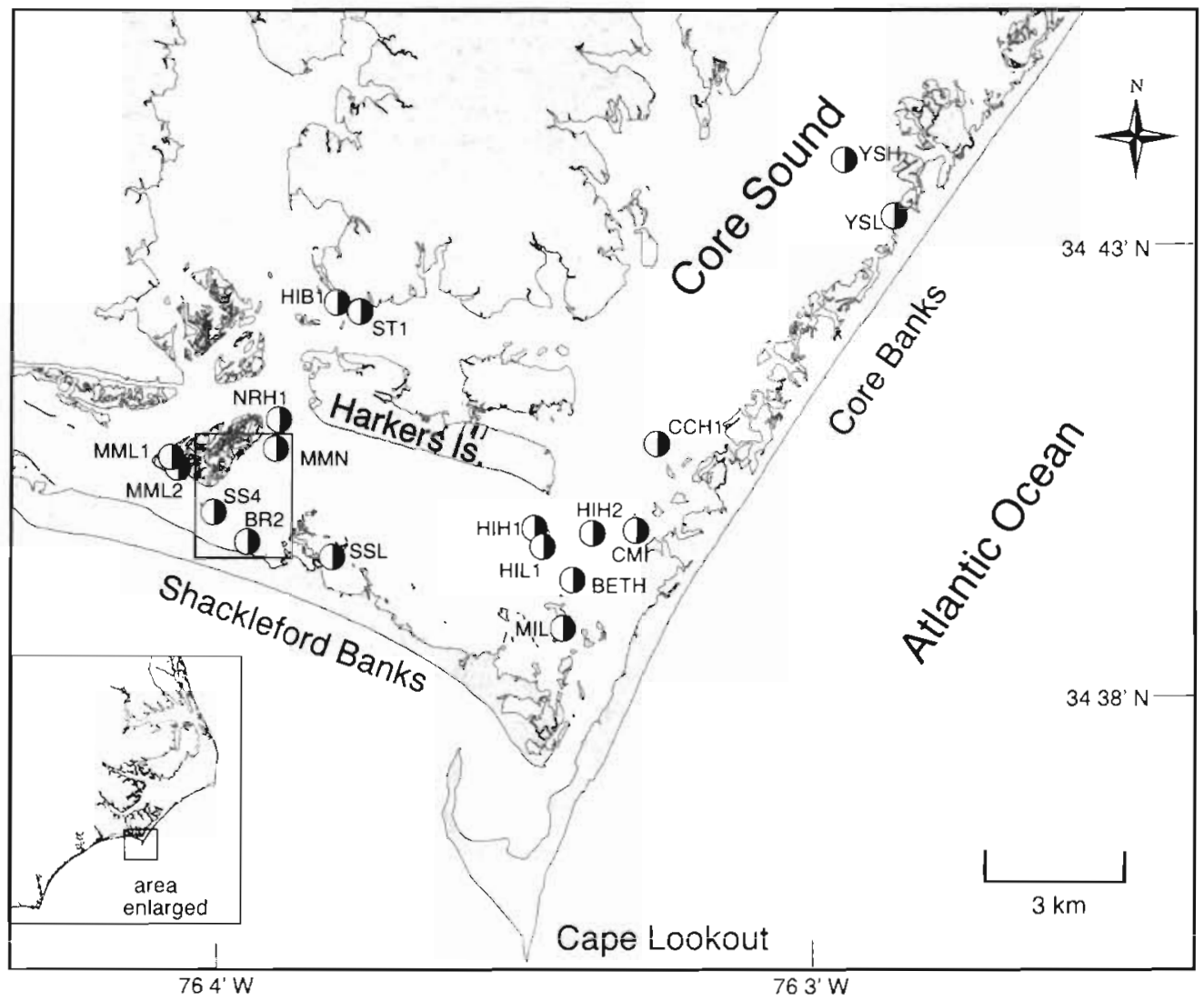

Fig. 1 Location of the eighteen $50 \times 50 \mathrm{~m}$ sites surveyed in spring and fall 1991 and 1992 near Beaufort, North Carolina. USA, marked with white/black dots. The 3 sites selected for detailed study are designated with a box around the dots

bioturbation although large decapod crustaceans (Callinectes spp., Menippe spp.) also were sometimes encountered on these sites (Table 1).

From these surveys, we theorized that the frequency and size of these pits could be sufficient to inhibit bed expansion through disruption of both seedling colonization and vegetative expansion of seagrass bed margins. The bioturbation pits were observed mostly in patchy seagrass beds rather than in continuous beds. Moreover, many pits occurred at seagrass bed margins, resulting in broken rhizomes, dislodging and exposing both roots and rhizomes and sometimes leaving the seagrass mat (shoots and attached roots and rhizomes) waving freely in the water column (authors' pers. obs.). These adventitious long shoots at the margins of the beds which we observed to be damaged are otherwise often primarily responsible for bed expansion (Duarte 1991, authors' pers. obs.).

Reiilling of bioturbation pits. Of the 18 sites surveyed, 3 sites were chosen that occurred in the middle range of the hydrodynamic gradient which was shown to be negatively correlated with seagrass coverage (Fonseca \& Bell 1998: $\mathrm{r}^{2}=0.45 ; \%$ cover $=-0.0135 \mathrm{REI}$. +92.525 ). This gradient was defined using a relative wave exposure index (REI; sites ranged from $\sim 0.5$ to $6.0 \times 10^{6}$; Table 2 ) and tidal current speed (range $\sim 5$ to $35 \mathrm{~cm} \mathrm{~s}^{-1}$; Table 2). REI was computed by summing among 8 compass headings (north, northeast, etc.) the

Table 1. List of potential bioturbators (as identified from the literature) found on the 3 sites selected for detailed study. Sampling conducted with $1 \mathrm{~m}$ throwtraps. $\mathrm{n}=3$ randomly placed throwtraps per site from a May-June survey, 1991

\begin{tabular}{|lll|}
\hline Site & Species & Sum \\
\hline br2 & Callinectes spp. & 7.3 \\
& Limulus polyphemus & 0 \\
& Menippe mercenaria & 0 \\
& Portunid crab spp. & 1.0 \\
mmn & Callinectes spp. & 10.7 \\
& Limulus polyphemus & 0 \\
& Menippe mercenaria & 0 \\
& Portunid crab spp. & 0 \\
ss4 & Callinectes spp. & 4.0 \\
& Limulus polyphemus & 0 \\
& Menippe mercenaria & 0 \\
& Opsanus tau & 1.0 \\
& Portunid crab spp. & 0 \\
& &
\end{tabular}


Table 2. Habitat attributes of eighteen $50 \times 50 \mathrm{~m}$ portions of seagrass beds in the Beaufort area (May-June 1992) arranged by REI (relative wave exposure index in millions). Bold rows: sites selected for detaled study. $\mathrm{SC}=$ silt-clay; OM = organic matter content; $\operatorname{Max} U=$ maximum current speed $\left(\mathrm{cm} \mathrm{s}^{-1}\right)_{i} \%$ cover = coverage at $\mathrm{m}$. resolution; biom. $=\mathrm{g}$ dry weight $\mathrm{m}^{-2} ; \mathrm{Z}-\mathrm{R}-\mathrm{H}=\mathrm{relative}$ percentage of seagrass shoots by species (Zostera marina, Ruppia maritima, Halodule wrightii); \% pits = disturbance pits surveyed at $1 \mathrm{~m}$ resolution within the eighteen $50 \times 50 \mathrm{~m}$ sites

\begin{tabular}{|c|c|c|c|c|c|c|c|c|c|c|}
\hline Site & REI & $\% \mathrm{SC}$ & $\%$ OM & $\operatorname{Max} U$ & $\%$ cover & $\begin{array}{l}\text { Shoot } \\
\text { density }\end{array}$ & $\begin{array}{l}\text { Above- } \\
\text { ground } \\
\text { biomass }\end{array}$ & $\begin{array}{l}\text { Below- } \\
\text { ground } \\
\text { biomass }\end{array}$ & $\mathrm{Z}-\mathrm{R}-\mathrm{H}$ & $\%$ pits \\
\hline ysh & 5.08 & 17 & 0.6 & 7 & 51 & 2923 & 78 & 488 & $12-0-88$ & 0.16 \\
\hline $\operatorname{cch} 1$ & 5.05 & 5 & 0.5 & 36 & 9 & 6486 & 56 & 368 & $2-0-98$ & 0.04 \\
\hline hih2 & 4.83 & 10 & 0.8 & 25 & 40 & 1248 & 77 & 1040 & $43-0-57$ & 0 \\
\hline beth & 4.62 & 15 & 0.4 & 29 & 3 & 2252 & 38 & 336 & $16-01-80$ & 1.3 \\
\hline hih1 & 3.78 & 7 & 0.4 & 35 & 22 & 3199 & 56 & 318 & $10-0-90$ & 0 \\
\hline nrh1 & 3.61 & 13 & 1.3 & 24 & 58 & 2519 & 106 & 357 & $31-11-58$ & 0.16 \\
\hline $\mathrm{mmn}$ & 3.08 & 9 & 0.7 & 25 & 44 & 1364 & 38 & 149 & $14-62-24$ & 0.08 \\
\hline hil1 & 2.30 & 14 & 1.1 & 18 & 87 & 403 & 31 & 75 & $81-0-19$ & 0.56 \\
\hline ysl & 1.96 & 12 & 1.2 & 5 & 100 & 4654 & 57 & 361 & $0-0-100$ & 0 \\
\hline $\mathrm{cmi}$ & 1.91 & 25 & 1.8 & 14 & 100 & 4779 & 46 & 304 & $7-0-93$ & 0 \\
\hline br2 & 1.89 & 10 & 1.0 & 26 & 40 & 1308 & 25 & 109 & $28-22-49$ & 1.3 \\
\hline $\operatorname{ss} 4$ & 1.52 & 8 & 0.8 & 24 & 74 & 3403 & 38 & 187 & $8-13-79$ & 1.04 \\
\hline $\mathrm{mil}$ & 1.21 & 28 & 1.2 & 23 & 77 & 5138 & 72 & 196 & $10-4-86$ & 0 \\
\hline st 1 & 1.03 & 40 & 2.0 & 7 & 99 & 1221 & 68 & 164 & $35-5-60$ & 0 \\
\hline ssl & 0.78 & 25 & 2.4 & 15 & 58 & 1500 & 246 & 273 & $75-0-25$ & 0 \\
\hline hib1 & 0.68 & 24 & 1.9 & 8 & 100 & 1589 & 52 & 116 & $28-57-15$ & 0 \\
\hline $\mathrm{mml2}$ & 0.62 & 25 & 1.4 & 10 & 97 & 1752 & 89 & 203 & $37-3-60$ & 0 \\
\hline $\mathrm{mml} 1$ & 0.54 & 35 & 3.5 & 18 & 78 & 523 & 90 & 90 & $100-0-0$ & 0 \\
\hline
\end{tabular}

product of wind speed, frequency of wind from that direction and effective fetch from that direction (Keddy 1982, Murphey \& Fonseca 1995, Fonseca \& Bell 1998). Tidal current speed was the peak velocity recorded on a site over a rising spring tide (Fonseca \& Bell 1998).

Spring and fall site surveys (May-June, OctoberNovember 1991 and 1992) indicated that sites in the middle to upper range of the REI gradient tended to have more bioturbation pits (Results; Table 2). Thus, we selected three, $50 \times 50 \mathrm{~m}$ sites for this study from the intermediate tidal current and REI range (see 'Results'; Table 2) at similar depths (Site br2 $=-0.07 \mathrm{~m}$ mean sea level; Site $\mathrm{mmn}=-0.31$; Site $\mathrm{ss} 4=-0.16$ ). The sites were located in an open bay, separated by tidal channels of at least $3 \mathrm{~m}$ depth and $100 \mathrm{~m}$ width, but within $3 \mathrm{~km}$ of each other.

Each of the 3 sites was divided into 25 equal, $10 \times 10 \mathrm{~m}$ subplots beginning in August 1992 (as almost all bioturbation pits were observed to be formed during the summer survey period of the 18 sites) The amount of coverage in each of these 25 subplots was computed from the most recent survey (May 1992) and 3 of the 25 subplots that contained $>50 \%$ unvegetated substrate were randomly selected. This was done to ensure that during subsequent site surveys we would detect some pit development as comparatively little bioturbation was observed on sites with higher bottom coverage (Table 2).

At the first survey visit in August 1992, existing bioturbation pits were identified and marked but were not included in our analysis because of their indeterminate age. Each subplot was visited every 1 to $3 \mathrm{~d}$ for $30 \mathrm{~d}$ and newly formed bioturbation pits were identified and marked with numbered survey flags, and measured for length, width, and depth. All previously marked pits were then remeasured. All pits were followed until there was no measurable difference in sediment elevation between the pit area and the surrounding sediment in a $1 \mathrm{~m}$ radius around the flag. Size-frequency of pit areas was calculated based on $5 \%$ changes in pit size relative to the $1.0 \mathrm{~m}^{2}$ resolution of the spring and fall surveys; the second increase in frequency for pit area classes (from small to large) was used as a demarcation of small versus large pit classes. Regression analysis (SAS 1989) was conducted on pit area over time, with and without subsequent reenlargement of the pits.

Pit to bed margin distances. In addition, we wanted to determine if pits were located significantly closer to seagrass bed margins than if they were randomly imposed on the landscape. If pits were closer to the seagrass bed margin than might be expected from a random draw, we posited that we could infer some preference on the part of the organisms forming the pits to target seagrass bed margins, a tactic that would maximize disruption of vegetative propagation and, thus, bed expansion. To do this, we used the mapping information from the seasons where bioturbation pits were detected (May-June 1991 . 1992; none were found in fall surveys) to conduct more 
detailed study of bioturbation pit distribution. We randomly chose thirty $1 \mathrm{~m}^{2}$ locations that were mapped as unvegetated bottom from each of the aforementioned three $50 \times 50 \mathrm{~m}$ sites. The distances from observed pits to seagrass bed margins and those of the 30 random locations were compared after combining all surveys (year and site) using a 1-way ANOVA on transformed data $(n+1)$ after an indication of heteroscedasticity using a Shapiro-Wilke test.

\section{RESULTS}

\section{Field surveys of bioturbation intensity}

Seagrass coverage on the sites was typically composed of patches several meters across, connected by narrow bands of cover with bioturbation pits interspersed near bed margins (Fig. 2). Based on the May-June 1991 and 1992 surveys of all 18 sites, sites with low REI values tended to have nearly complete coverage of the bottom, moderate belowground biomass that would intertere with bioturbation and few, if any, pits (Table 2). Sites with high hydrodynamic activity and even higher belowground bio-

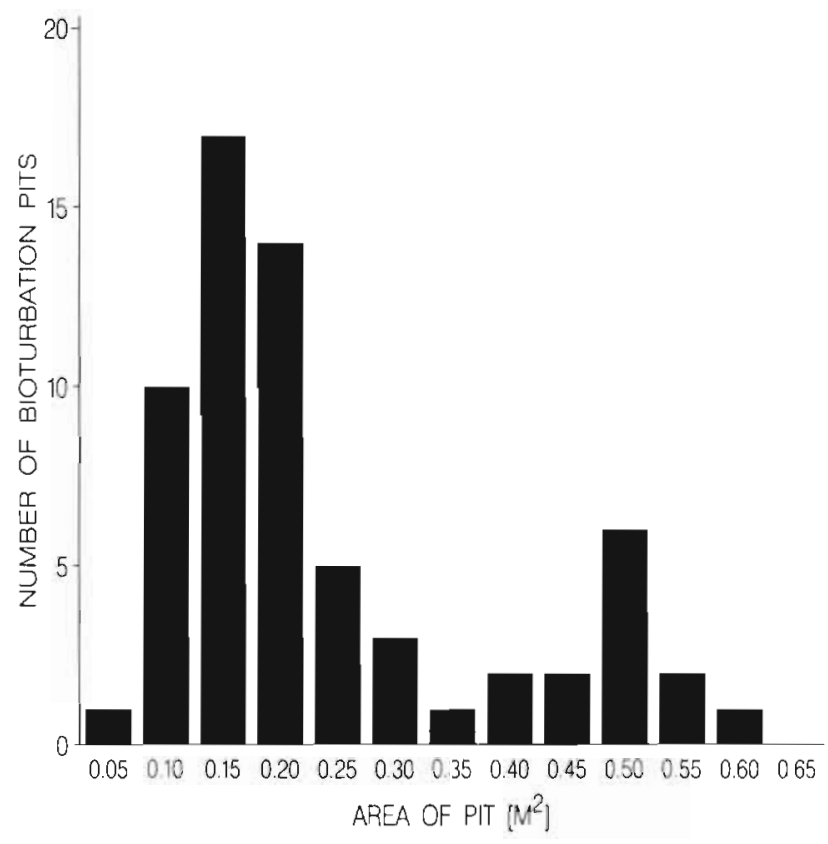

Fig. 3. Frequency distribution of bioturbation pits at time of formation as recorded during the August 1992 survey of the 3 detailed study sites (br2, mmn, ss4; Table 2). Size classes chosen at $5 \%$ increments on a $1 \mathrm{~m}^{2}$ scale. Small pits are those $\leq 0.4 \mathrm{~m}^{2}$; large pits are $>0.4 \mathrm{~m}^{2}$

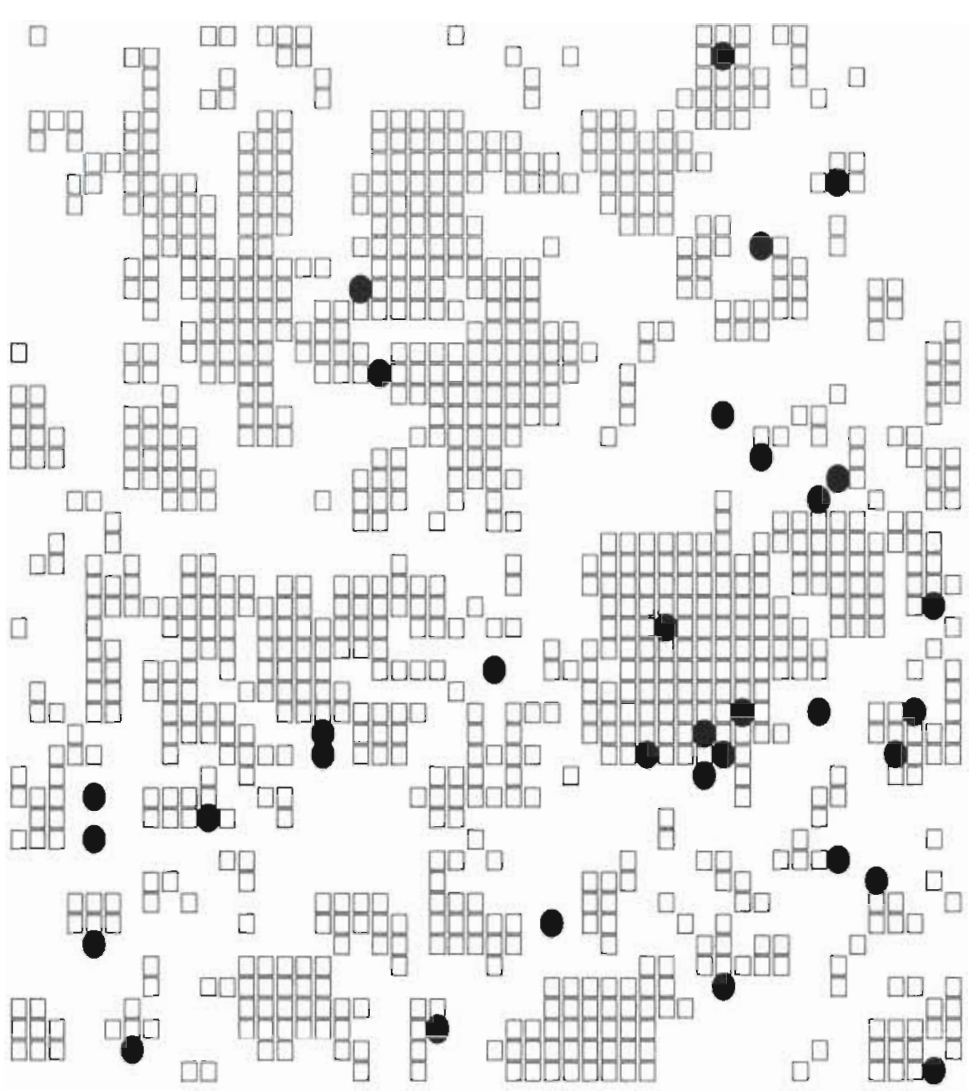

Fig. 2. Digital rendition of a $50 \times 50 \mathrm{~m}$ site survey performed at $1 \mathrm{~m}$ resolution. Site is br2 (Table 2) during the spring 1991 survey. Squares indicate $1 \mathrm{~m}^{2}$ areas surveyed as seagrass. Open areas indicate unvegetated sand. Black dots indicate ray pits

mass were also found to have few bioturbation pits. No bioturbation pits were detected during fall surveys (October-November 1991 and 1992). Sites in the middle to upper range of the REI gradient tended to have more bioturbation pits (Table 2).

\section{Refilling of bioturbation pits}

We found a bimodal distribution of August 1992 bioturbation pit size classes which were categorized as either small pits $\left(\leq 0.4 \mathrm{~m}^{2}\right.$ : all pit classes smaller than the second cohort; the second cohort was considered to occur after the first increase in pit class frequency after declining frequencies when proceeding from small to large pit classes) or large $\left(>0.4 \mathrm{~m}^{2}\right)$ (Fig. 3$)$. The majority $(n=53)$ of pits were of the small category, ranging between 0.05 and $0.4 \mathrm{~m}^{2}$ in area at formation. Relatively few ( $n=11$ ) were found in the large size category (>0.4 to $0.6 \mathrm{~m}^{2}$ range) (Fig. 3). Maximum pit size approached a square meter of seafloor and a quarter of a cubic meter of displaced sediment (Table 3). Mean and maximum pit depths (Table 3 ) equal or exceed that 


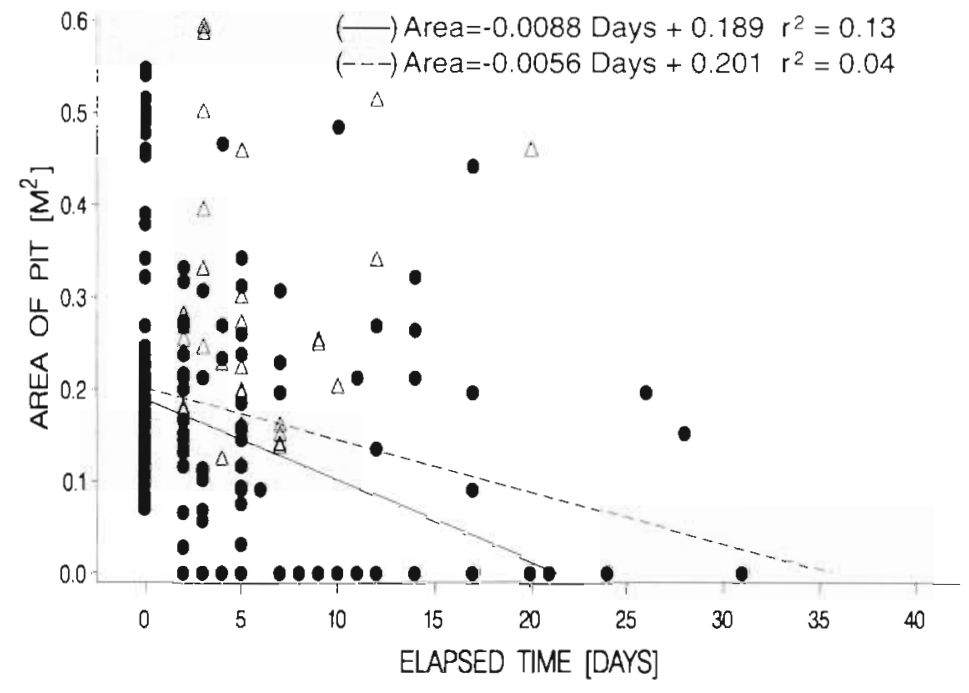

Fig. 4. Linear regression showing refilling of bioturbation pits with and without subsequent reenlargements included. ( $\bullet$ Refilling of pits with reenlargements. $(\Delta)$ Refilling of pits without reenlargements. Dashed line: regression line with reenlargements included. Solid line: regression line with reenlargements excluded. Elapsed time is time since pit formation

of the rhizome depth of the local dominant seagrass species, Zostera marina and Halodule wrightii (1 to $5 \mathrm{~cm}_{\text {i }}$ authors' pers. obs.).

The total area of the small pits $\left(<0.4 \mathrm{~m}^{2}\right)$ was $1.41 \mathrm{~m}^{2}$, while the pits $>0.4 \mathrm{~m}^{2}$ totaled $2.17 \mathrm{~m}^{2}$ or approximately 1.5 times that of the smaller pits. Linear regressions of pit refilling over time predicted that the maximum duration of a pit was approximately $35 \mathrm{~d}$ ( $x$-intercept) with a mean of $16 \mathrm{~d}$ whereas simple means of refilling time by pit category indicated that the large category pits required up to a month to refill, while the majority of pits (small category) refilled in $\sim 5 \mathrm{~d}$. The large category pits often were enlarged beyond their original size at formation after about $15 \mathrm{~d}$, apparently due to additional bioturbation. Removal of reenlarged pits from the analysis reduced the predicted maximum duration to $-22 \mathrm{~d}$ with a predicted mean of $9 \mathrm{~d}$ until refilling (Fig. 4). The smaller, more frequently encountered pits tended to refill in a linear fashion. To better

Table 3. Survey data of newly formed bioturbation pits taken from 3 selected sites, August 1992. Time = days for pit to fill; pit depth, area and volume refer to dimensions at formation

\begin{tabular}{|lcc|}
\hline Variable & Mean & Maximum \\
\hline Time $(\mathrm{d})$ & 5.3 & 31.0 \\
Pit depth $(\mathrm{cm})$ & 4.2 & 12.0 \\
Area $\left(\mathrm{m}^{2}\right)$ & 0.17 & 0.87 \\
Volume $\left(\mathrm{m}^{3}\right)$ & 0.04 & 0.26 \\
\hline
\end{tabular}

show the interaction of pit size at formation, time to refilling, and reenlargement, we plotted the data in a 3-dimensional format (Fig 5); the peak in reenlargement for the fewer, large-size pits is revealed to have occurred near $21 \mathrm{~d}$ after initial formation. There were no unusual storm events during the period of our surveys thus, these pit refilling rates are likely representative of chronic rather than acute hydrodynamic conditions at these sites.

Because of the importance bioturbation may have for the heterogeneity of the seagrass landscape, we calculated the frequency with which any particular square meter of currently unvegetated bottom would be expected to experience pit formation. Using the average area of unvegetated bottom on a site from our May-June 1991 and 1992 surveys, and the frequency of new pit formation in unvegetated areas from the August 1992 pit filling survey, we computed that any square meter of unvegetated bottom within our study areas would experience a bioturbation pit approximately every $1.2 \mathrm{yr}$.

\section{Pit to bed margin distances}

Using the seasonal surveys of these sites mapped at the $1 \mathrm{~m}$ scale (May-June 1991 and 1992), 1-way ANOVA showed no significant difference $(p>0.05, F=$

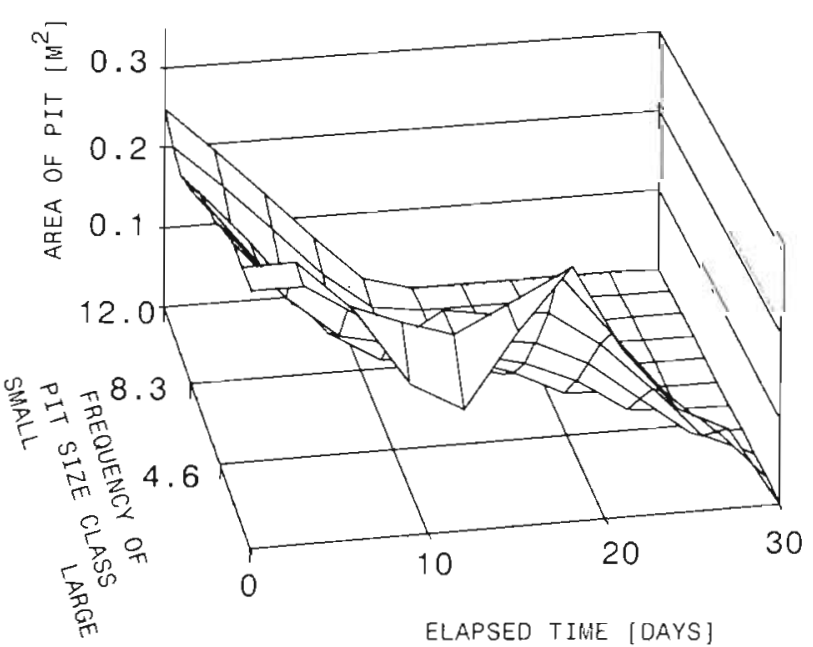

Fig. 5. Three-dimensional display of the interaction of pit size at formation $\left(\mathrm{m}^{2}\right)$, elapsed time since pit formation, and the change in pit area as refilling occurs. Note that small, more frequently formed pits go to 0 area (refilled) more rapidly than larger pits that are reenlarged approximately $15-20 \mathrm{~d}$ after formation 
Table 4. Frequency of pits by distance from nearest grass edge with cumulative percentage of total number of pits observed, by distance. Distances obtained from site maps of eighteen $50 \times 50 \mathrm{~m}$ areas surveyed in spring 1991 and 1992

\begin{tabular}{|lccc|}
\hline $\begin{array}{l}\text { Survey } \\
\text { season }\end{array}$ & $\begin{array}{c}\text { Distance } \\
\text { from } \\
\text { grass }(\mathrm{m})\end{array}$ & $\begin{array}{c}\text { Frequency } \\
\text { (no. of } \\
\text { pits) }\end{array}$ & $\begin{array}{c}\text { Cumulative } \\
\text { percentage }\end{array}$ \\
\hline May-June 1991 & 0 & 90 & 73.2 \\
& 1 & 19 & 88.6 \\
& 2 & 11 & 97.6 \\
& 3 & 2 & 99.2 \\
May-June 1992 & 4 & 1 & 100.0 \\
& 0 & 57 & 56.4 \\
& 1 & 18 & 74.3 \\
& 2 & 4 & 78.2 \\
& 3 & 8 & 86.1 \\
& 4 & 3 & 89.1 \\
& 5 & 3 & 92.1 \\
& 6 & 2 & 94.1 \\
& 7 & 2 & 96.0 \\
& 8 & 1 & 97.0 \\
& 9 & 3 & 100.0 \\
\hline
\end{tabular}

$1.00)$ between observed pit-bed margin distances ( $\mathrm{n}=$ 224) and that of randomly selected bare sand-bed margin distances taken from these survey maps $(n=360)$. However, when ranked by proximity to bed margins, in May-June 1991, $73 \%$ of the observed pits were immediately adjacent $(<1 \mathrm{~m})$ to seagrass cover, while in May-June 1992, 56\% were adjacent to seagrass (Table 4). In May-June 1991, all pits were located within $4 \mathrm{~m}$ of seagrass bed margins, while in MayJune 1992 pits were observed up to $9 \mathrm{~m}$ from seagrass bed margins (Table 4). We observed few pits formed that were surrounded by seagrass; most pits appeared to be at bed margins or in open sand areas (e.g. Fig. 2). We did not observe any colonization of pits by seagrass, but rhizome extension rates for these seagrasses are such that little movement into pits would be expected within a month (longest observed time to pit refilling). Again, broken and dislodged rhizomes were observed on the margins of pits adjacent to seagrass beds.

\section{DISCUSSION}

Even though a small portion of the unvegetated area among the seagrass patches shows signs of disturbance at any one time $(<2 \%$; e.g. Fig. 2$)$, the frequency of pit formation is high enough so that any square meter of unvegetated bottom (at least in the sites of intermediate coverage and REI) over at least a $1 / 4$ ha area is likely to be disturbed by bioturbation every $\sim 1.2$ yr on average. Unlike Valentine et al.'s (1994) finding for Thalassia testudinum beds, pit depths here were often greater than the depth of seagrass rhizomes (which occur within $\sim 1$ to $5 \mathrm{~cm}$ of the sediment surface; authors' pers obs.), meaning that bioturbators could damage bed margins through root-rhizome disruption and dislodge any seeds or seedlings. Like the findings of Valentine et al. (1994), it appeared that bioturbation pits were formed on the edge of existing seagrass, and animals apparently did not often create pits in areas surrounded by seagrass at the $1 \mathrm{~m}$ scale, a finding consistent with that of Peterson et al. (1984) who found little evidence of effective burrowing through seagrass root-rhizome mats in the Beaufort area (but see Orth 1975).

Although the majority $(>80 \%)$ of the pits observed were $\leq 0.4 \mathrm{~m}^{2}$ in area, the large numbers of these small pits over these $1 / 4$ ha areas could have a cumulative effect on bed heterogeneity. Larger pits, although fewer, accounted for 1.5 times more disturbed seafloor than the more numerous smaller pits. However, the effect of pit disturbance on bed margins would then decline as the square root of the area of the pit. Another way to view the influence of the larger pits is to consider that if all the pits were laid side by side and centered precisely along seagrass bed margins, the sum total of seagrass bed margin being disrupted by the larger pits would only be $-35 \%$ of that disrupted by the more numerous, smaller pits. This suggests that disturbance effects from the larger pits might be more profound in terms of chemical alteration of sediments or infusion of organic material into the sediment (sensu Yager et al. 1993) than their overall disruption of seagrass bed margins.

Although we did not observe any pit colonization by seagrass in the August 1992 study, this is likely due to a combination of rapid refilling ( $~ 30 \mathrm{~d}$ maximum time to refill) and low intrinsic rhizome extension rates (authors' pers obs:; up to $\sim 6.5$ and $3.4 \mathrm{~cm} \mathrm{mo}^{-1}$, for Halodule wrightii and Zostera marina, respectively; Duarte 1991, Gallegos et al. 1994), especially with potential damage to the rhizome apicals. However, as seen in other studies of disturbance (sensu Sousa 1985), the size of the disturbance influenced recovery (here, refilling) speed, and simple extent of pit size at formation did not always predict refilling. Large pits tended to refill more slowly than small pits (Fig. 4) because of further disruption which occurred some time after initial formation (Fig. 5). We observed these reenlargements to often appear in the form of what appeared to be a new, overlapping pit. Therefore, we posit that this reenlargement was due to additional bioturbation where fauna used the large pit opportunistically, by continuing the excavation, presumably at lower cost to the burrowing organism than would be realized by initiating a new pit. 
Previous studies have examined the rate at which seagrass can recolonize disturbed areas (Zieman 1976 , Durako et al. 1992, Fonseca et al. 1994). However, these studies were set where undisturbed seagrass surrounded the disturbance area. Bed margins, which occupy new space via vegetative expansion on one front only, should expand more slowly than in these previous studies, particularly when there has been a disturbance of the adjacent sand. Thus, we feel that when taken together - the $\sim 1.2$ yr frequency of disturbance, the concentration of disturbance near bed margins, pits being formed at depths that usually exceed that of these seagrass species' rhizomes, and our field observations of rhizome damage when pits bordered seagrass patches - these levels of bioturbation could significantly impair the expansion of local, mixed Zostera-Halodule seagrass bed margins. Therefore, bioturbation may play an important role in the maintenance of local seagrass bed landscape pattern. Bioturbation might also influence the origin of these patterns if it were acting on developing beds, as occurs in particular with portions of many $Z$. marina beds that annually rely on seeds for bed maintenance (Thayer et al. 1984, Orth et al. 1994). Moreover, these seagrass beds experience biological disturbance year after year, making bioturbation a chronic feature of the disturbance regime which enhances the potential contribution of bioturbation to the landscape pattern of the seagrass beds.

As was shown above, numerous small disturbance events have the potential to cause nearly as much disruption of seagrass bed margins than a few large disturbance events. Assuming that pit size scales with animal size or intensity of feeding by a group of animals, we ask which species might be the major sources of these bioturbation pits? While we did not attempt to observe the organisms responsible for the bioturbation pits, numerous potential candidates are known to use the seagrass beds we studied (Table 1). The smaller pits could be the result of feeding or burrowing activity by blue crabs Callinectes sapidus, stone crabs Menippe mercenaria, oyster toadfish Opsanus tau or aborted feeding activity of rays (Orth 1975). Although not represented in Table 1 (the gear used to capture the fauna in Table 1 is biased towards small seagrassbed residents), the larger pits could result from the feeding activity of the cownose ray Rhinoptera bonasus and southern stingray Dasyatis americana or the activities of flounder or horseshoe crabs. The largest influx of rays into North Carolina estuaries (early spring) coincides with the annual peak of sexual reproduction by Zostera marina, but occurs well after the onset of seed germination that starts in December. This spring timing of ray influx however, does coincide with the time for rapid seedling growth (Kenworthy et al.
1980), creating an opportunity to strongly impact the colonization of new, unvegetated seafloor by $Z$. marina, even in the absence of direct predation on seeds (Wigand \& Churchill 1988). Otherwise, all of the animal species mentioned are year-round residents so the possibility of bioturbation effects on the grass beds, though reduced during the winter, is ever present.

Data obtained from mapping seagrass beds across a gradient of hydrodynamic regimes (Fonseca \& Bell 1998 ) indicates that the most detectable bioturbation occurs in beds found in the mid-range of hydrodynamically-mediated disturbance (REI) in this estuarine system. The higher belowground seagrass biomass found on sites with higher hydrodynamic activity may impair bed bioturbation (sensu Peterson et al. 1984, Irlandi \& Peterson 1991), although pits appeared to be formed in unvegetated areas even in lower flow sites. We must also acknowledge that the comparatively higher wave and tidal currents at the very patchy sites may act to rapidly obscure pits, thus potentially biasing our survey estimates of bioturbation intensity at these sites downward. But even at the levels of bioturbation observed in beds within the mid-range of local hydrodynamic conditions, we predict that bioturbation would produce an additional depression of coverage to that already imposed by tidal currents and REI. Besides potentially inhibiting lateral spread of beds, and occasionally burrowing into and fragmenting existing beds, bioturbation could influence other bedforming processes, such as disrupting connections among patches. Breaking connections among seagrass patches decreases the percolation of the seagrass pattern (sensu With \& Crist 1995). Fonseca \& Bell (1998) theorize that breaks in these among-patch connections strongly contribute to an observed threshold response involving seagrass cover and hydrodynamic setting, where seagrass-bed coverage drops quickly with small changes in hydrodynamic activity at a site (Fonseca \& Bell 1998). Therefore, bioturbation may contribute not only to pattern expression of existing beds through bed margin disruption, but could theoretically lead to the birth of new, discrete beds by breaking connections among existing patches, creating the potential for subsequent hydrodynamically derived erosion.

We have shown bioturbation to be a consistent feature of fragmented seagrass beds over landscape scales (10's of meters). Moreover, as shown by Valentine et al. (1994) for Menippe spp., the disturbance level we observed has the capability to limit the extension of the seagrass-bed margin. Any consideration of functions of seagrass beds that may be influenced by landscape pattern (e.g. faunal utilization, sensu With \& Crist 1995) should recognize the landscape-scale contribution of bioturbation and not just those arising from hydrodynamic processes. 
Acknowledgements. We are grateful for all of the assistance provided by the staff of NMFS, Beaufort Laboratory, especially Paula Whitfield and Dave Meyer. Reviews by Susan Bell, Maurice Crawford, Wayne Sousa, and 2 anonymous reviewers greatly improved the manuscript. Funding was provided by NOAA's Coastal Ocean Program (Grant EHP-23 to M.S.F.) and the National Marine Fisheries Service, Beaufort Laboratory

\section{LITERATURE CITED}

Bell SS, Hall MO, Fonseca MS (1994) Evaluation of faunal and floral attributes of seagrass beds in high and low energy regimes: a geographic comparison. In: Dyer KR, Orth RJ (eds) Changes in fluxes in estuaries: implications from science to management. Olsen and Olsen Press, Fredensborg, p 267-272

Billheimer LE, Coull BC (1988) Bioturbation and recolonization of meiobenthos in juvenile spot (Pisces) feeding pits. Estuar Coast Shelf Sci 27:335-340

Camp DK, Cobb SP, Van Breedveld JF (1973) Overgrazing of seagrass by a regular urchin Lytechinus variegatus. Bioscience 23:37-38

den Hartog C (1971) The dynamic aspects in the ecology of seagrass communities. Thalass Jugoslav 1:101-112

Duarte CM (1991) Allometric scaling of seagrass bed form and productivity. Mar Ecol Prog Ser 77:289-300

Durako MJ, Hall MO, Sargent F, Peck S (1992) Propeller scars in seagrass beds: an assessment and experimental study of recolonization in Weedon Island State Preserve Florida. In: Webb WJ (ed) Proc of the 19th Annual Conference on Wetlands Creation and Restoration, May 14-15, 1992. Hillsborough Community College, Tampa, FL, p 42-53

Eckman JE, Nowell ARM, Jumars PA (1981) Sediment destabilization by animal tubes. J Mar Res 39:361-374

Fonseca MS (1996) Scale dependence in the study of seagrass systems. In: Kuo J, Phillips RC, Walker DL, Kirkman $\mathrm{H}$ (eds) Seagrass biology: Proceedings of an International Workshop, Rottnest Island, Western Australia. Faculty of Sciences, The University of Western Australia, Nedlands, WA, p 95-104

Fonseca MS Bell SS (1998) The influence of physical setting on seagrass landscapes near Beaufort, North Carolina, USA. Mar Ecol Prog Ser (in press)

Fonseca MS, Kenworthy WJ, Courtney FX, Hall MO (1994) Seagrass planting in the southeastern United States: methods for accelerating habitat development. Rest Ecol $2: 198-212$

Fonseca MS, Zieman JC, Thayer GW, Fisher JS (1983) The role of current velocity in structuring eelgrass (Zostera marina) meadows. Estuar Coast Shelf Sci 17:367-380

Gallegos ME, Merino M, Rodriguez A, Marba N, Duarte CM (1994) Growth patterns and demography of pioneer Caribbean seagrasses Halodule wrightii and Syringodium filiforme. Mar Ecol Prog Ser 109:99-104

Grant J (1983) The relative magnitude of biological and sediment reworking in an intertidal community. J Mar Res 41. $673-689$

Harrison PG (1987) Natural expansion and experimental manipulation of seagrass (Zostera spp.) abundance and the response of infaunal invertebrates. Estuar Coast Shelf Sci 24:799-812

Irlandi EA. Peterson CH (1991) Modification of animal habitat by large plants: mechanisms by which seagrasses affect clam growth. Oecologia 87:307-318

Keddy PA (1982) Quantifying within-lake gradients of wave energy: interrelationships of wave energy, substrate particle size and shoreline plants in Axe Lake, Ontario. Aquat Bot 14:41-58

Kenworthy WJ, Fonseca MS, Homziak J, Thayer GW (1980) Development of a transplanted seagrass (Zostera marina L.) meadow in Back Sound, Carteret County, North Carolina. In: Cole DP (ed) Proc of the 7th Annual Conference for Restoration and Creation of Wetlands. Hillsborough Community College, Tampa, FL, p 175-193

Kirkman H, Kuo J (1990) Pattern and process in southern Western Australian seagrasses. Aquat Bot 37:367-382

Murphey PE, Fonseca MS (1995) Role of high and low energy seagrass beds as nursery areas for Penaeus duorarum in North Carolina. Mar Ecol Prog Ser 121:91-98

Ogden JC, Brown RA, Salesky N (1973) Grazing by the echinoid Diadema antillarum Philippi: formation of halos around West Indian patch reefs. Science 182:715-717

O'Gower AK, Wacasey JW (1967) Animal communities associated with Thalassia Diplanthera and sand beds in Biscayne Bay 1. Analysis of communities in relation to water movements. Bull Mar Sci 17(1):175-201

Orth RJ (1975) Destruction of eelgrass Zostera marina by the cownose ray Rhinoptera bonsaus in the Chesapeake Bay. Cheaspeake Sci 16:205-208

Orth RJ, Luckenbach M, Moore KA (1994) Seed dispersal in a marine marcrophyte: implications for colonization and restoration. Ecology 75:1927-1939

Patriquin DG (1975) 'Migration' of blowouts in seagrass beds at Barbados and Carriacou West Indies and its ecological and geological applications. Aquat Bot 1:163-189

Peterson CH, Summerson HC, Duncan PB (1984) The influence of seagrass cover on population structure and individual growth rate of a suspension-feeding bivalve Mercenaria mercenaria. J Mar Res 42:123-138

Philippart CJM (1994) Interactions between Arenicola marina and Zostera noltii on a tidal flat in the Wadden Sea. Mar Ecol Prog Ser 111:251-257

Rhoads DC, Young DK (1971) Animal-sediment relations in Cape Cod Bay Massachusetts II. Reworking by Molpadia oolitica (Holothuroidea). Mar Biol 11:255-261

Sargent FJ, Leary TJ, Crewz DW, Kruer CR (1995) Scarring of Florida's seagrasses: assessment and management options. FMRI Tech Rep TR-1. Florida Marine Research Institure, St. Petersburg

SAS (1989) SAS/STAT users guide, version 6, 4 th edn, Vol 2. SAS Institute, Cary, NC

Scoffin TP (1970) The trapping and binding of subtidal carbonate sediments by marine vegetation in Bimini Lagoon, Bahamas. J Sediment Petrol 40:249-273

Short FT, Wyllie-Echeverria S (1996) Natural and humaninduced disturbances of seagrasses. Environ Conserv 23: $17-27$

Sousa WP (1985) Disturbance and patchy dynamics on rocky intertidal shores. In: White PS Pickett STA (eds) The ecology of natural disturbance and patch dynamics. Academic Press, New York, p 101-124

Suchanek TH (1983) Control of seagrass communities and sediment distribution by Callianassa (Crustacea Thalassinidea) bioturbation. J Mar Res 41:281-298

Taylor JD, Lewis MS (1970) The flora, fauna and sediments of the marine grass beds of Mahé, Seychelles. J Nat Hist 4: $199-220$

Thayer GW, Kenworthy WJ, Fonseca MS (1984) The ecology of eelgrass meadows of the Atlantic coast: a community profile. Fish Wildl Serv Biol Rep FNS/OBS-84/02

Thrush SI, Pridmore RD, Hewitt JE, Cummings VJ (1991) Impact of ray feeding disturbances on sandflat 
macrobenthos: do communities dominated by polychaetes or shellfish respond differently? Mar Ecol Prog Ser 69 . $245-252$

Valentine JF, Heck KL (1991) The role of sea urchin grazing in regulating subtropical seagrass meadows: evidence from field manipulations in the northern Gulf of Mexico. J Exp Mar Biol Ecol 154:215-230

Valentine JF, Heck KL, Harper P, Beck M (1994) Effects of bioturbation in controlling turtlegrass (Thalassia testudinum Banks ex Konig) abundance: evidence from field enclosures and observations in the northern Gulf of Mexico. J Exp Mar Biol Ecol 178:181-192

White PS, Pickett STA (1985) Natural disturbances and Patch

Editorial responsibility: Kenneth Heck (Contributing Editor), Dauphin Island, Alabama, USA dynamics: An introduction. In: Pickett STA, White PS (eds) The ecology of natural disturbances and patch dynamics Academic Press, Orlando, p 3-13

Wigand C, Churchill DC (1988) Laboratory studies on eelgrass seed and seedling predation. Estuaries 11:80-183

With KA, Crist TO (1995) Critical thresholds in species' responses to landscape structure. Ecology 76:2446-2459

Yager PL, Nowell ARM, Jumars PA. (1993) Enhanced deposition to pits: a local food source for benthos. J Mar Res 51 $209-236$

Zieman JC (1976) The ecological role of physical damage from motor boats on turtlegrass beds in southern Florida Aquat Bot 2:127-139

Submitted: March 6, 1996; Accepted: May 5, 1998

Proofs received from author(s): June 30, 1998 